UNITED STATES DEPARTMENT OF THE INTERIOR

GEOLOGICAL SURVEY

\title{
MINERAL RESOURCE POTENTIAL OF THE LAKE ELEANOR \\ ROADLESS AREA, TRINITY COUNTY, CALIFORNIA
}

\author{
by \\ Donald F. Huber \\ Scott C. Nelson \\ U.S. Geological Survey \\ and \\ Eric E. Cather \\ Joseph L. Ritchey \\ U.S. Bureau of Mines \\ U.S. Geological Survey \\ Open-File Report 83-482 \\ 1983
}




\section{STUDIES RELATED TO WILDERNESS}

Under the provisions of the Wilderness Act (Public Law 88-577, September 3,1964 ) and related acts, the U.S. Geological Survey and the U.S. Bureau of Mines have been conducting mineral surveys of wilderness and primitive areas. Areas officially designated as "wilderness," "wild," or "canoe" when the act was passed were incorporated into the National Wilderness Preservation System, and some of them are presently being studied. The act provided that areas under consideration for wilderness designation should be studied for suitability for incorporation into the Wilderness System. The mineral surveys constitute one aspect of the suitability studies. The act directs that the results of such surveys are to be made available to the public and be submitted to the President and the Congress. This report discusses the results of a mineral survey of the Lake Eleanor Roadless Area (5807), Shasta-Trinity National Forest, Trinity County, California. The Lake Eleanor Roadless Area was classified as a further planning area during the Second Roadless Area Review and Evaluation (RARE II) by the U.S. Forest Service, January 1979.

\section{SUMMARY}

On the basis of investigations by Hotz and others (1972), and herein, there is no evidence of a potential for metallic mineral resources in the Lake Eleanor Roadless Area. The study by Hotz and others (1972) consisted of geological, geochemical, and geophysical surveys and mine and prospect examinations in an area that includes most of the roadless area. The present investigation focused on the parts of the roadless area not included in the earlier study and includes additional geochemical analyses and geologic mapping by the U.S. Geological Survey. The U.S. Bureau of Mines conducted mining and production surveys and additional sampling. Fissure veins yielding gold, silver, copper, and lead that occur one mile north of the study area do not extend into the roadless area. There are no geochemical anomalies, no identified lode or placer resources, and no known history of mining activity in the roadless area. The fact that surrounding areas have been extensively explored and mined almost eliminates the possibility of additional surficial lode gold deposits in the roadless area. There is no evidence of a potential for non-metallic and energy resources in the roadless area.

\section{INTRODUCTION}

The Lake Eleanor Roadless Area is located in the southern part of the Klamath Mountains geologic province about 14 to $28 \mathrm{mi}$ north-northeast of Weaverville, Trinity County, California (fig. 1). The area is situated in the Trinity Alps, a part of the Klamath Mountains which is an elongate north-trending mountainous region in northwest California. The roadless area encompasses 14,300 acres of Shasta National Forest, whereas a small southern part is in the Trinity National Forest. The roadless area extends $13 \mathrm{mi}$ on the Coffee Creek and Trinity Dam 15-minute Quadrangles and wraps around the eastern and northeast border of the proposed, Salmon-Trinity Alps Wilderness. Access to the northern and eastern borders of the roadless area is by foot trails leading from various unimproved dirt roads that lead from paved State Highway 3 and Coffee Creek Road. 
Additional access exists from trail heads off the Stuart Fork and the East Stuart Fork of the Trinity River and Swift Creek. Elevations above sea level range from $3770 \mathrm{ft}$ along Swift Creek in the southern half, to $7919 \mathrm{ft}$ on Battle Mountain in the northwest part of the roadless area. The terrain is very rugged owing to glacial scouring and to dissection by numerous streams.

The area is typified by a dense timber cover of pine, fir, cedar, spruce, and other evergreens predominating above $4000 \mathrm{ft}$. Oak, laurel, maple, madrone, and other deciduous trees grow at lower elevations and in valleys. Manzanita and other plants of the chaparral community are an impediment to hiking on steep slopes. Drainage in the roadless area consists of northward-flowing tributaries into Coffee Creek and northeast-to-southeast-flowing tributaries that empty into the Trinity River.

Approximately 13,200 acres of the Lake Eleanor Roadless area are included in the geologic map of the Salmon-Trinity Alps Primitive Area, California (Hotz and others, 1972). The geology of the remaining 1100 acres is included in Strand's (1962) compilation of the Redding Sheet. During this study, aerial photo interpretation and field checking was used to define the extent of the Quaternary units within the southernmost part of the roadless area. Field checking and stream-sediment sampling were done by the Geological Survey during June 1980, and June and December 1981. Nine stream sediment samples were collected and analyzed for gold, platinum-group metals, and other elements.

The U.S. Bureau of Mines, Western Field Operations Center, searched published literature, as well as records of the U.S. Bureau of Mines, Trinity County, U.S. Bureau of Land Management and the U.S. Forest Service for data concerning mineral deposits, claims, leases, and production, and mining activity in the roadless area. The Bureau of Mines conducted field work in the summer of 1981 that involved searching for prospects, claim locations, and mineralized zones not included in the earlier investigation. The search was aided by the use of a helicopter. Ten placer samples were collected from stream gravels in the area and analyzed for gold. Some prospects may have been overlooked because of the rugged terrain and dense vegetation.

\section{GEOLOGIC SETTING}

The Lake Eleanor Roadless Area is almost entirely in the Trinity ultramafic sheet, the western part of the eastern Klamath belt in the Klamath Mountains geologic province (fig. 2). The Trinity ultramafic sheet is the largest exposure of ultramafic rocks in North America, and is one of several 1ithic belts that constitute the province. These imbricate arcuate lithic belts (convex side facing west) are thought to represent eastward-dipping thrust slices of oceanic crust and island arcs that were accreted to the continental margin by plate tectonic processes during Mesozoic time. The sheet is thought to be part of an ophiolitic assemblage that is Ordovician or older in age (Irwin, 1977).

The ultramafic rocks dip eastward beneath the Paleozoic rocks of the eastern Klamath belt. The ultramafic sheet is underthrust by the rocks of the central metamorphic belt along a fault at the base of the ultramafic sheet. The age of thrusting may be coincidental with Devonian metamorphism of the central metamorphic belt (Irwin, 1977). 
The central metamorphic belt extends for $99 \mathrm{mi}$ and ranges in width from less then $0.5 \mathrm{mi}$ in the north to 12 miles in the south. The belt consists of two coextensive formations, the Salmon Hornblende Schist and the Abrams Mica Schist. The Salmon lies structurally below the Abrams and is a 0.5- to 1 mi-thick mafic metavolcanic unit that underwent amphibolite facies metamorphism dứring Devonian time (Irwin, 1977). The Abrams consists of metamorphosed sediments deposited in a eugeosynclinal environment (Davis and others, 1965).

Several granitic plutons intruded the ultramafic and metamorphic rocks during the Mesozoic, especially along the western margin of the Trinity ultramafic sheet. Most of the plutons are elongate north-south, parallel to the regional structural trend. The largest is 6 to $7 \mathrm{mi}$ across. The larger plutons are composite, or zoned, and range in composition from mafic peripheries to silicic cores, and have moderate to well developed concentric follation.

The Klamath region was subjected to alpine glaciation during the Pleistocene, leaving spectacular scenery in the form of sawtooth ridges, U-shaped valleys, matterhorn peaks, ice-scoured bedrock, and moraines. Stream-terrace and channel deposits occur in all major drainage basins.

The northwestern and southern parts of the roadless area are underlain by ultramafic rocks (fig. 3). They consist of serpentinized peridotite, serpentine, and small amounts of serpentinized dunite, and subordinate dunite and pyroxenite. Mineralogically, the peridotite consists of olivine and enstatite. Some serpentinite may contain highly variable amounts of unaltered olivine and pyroxene, accompanied by small scattered grains of chromite; where fresh, the peridotite is green-black and forms massive jointed outcrops. Where weathered, deep red-brown solls are common. Compositional layering, considered a primary structure, occurs in some ultramafic rocks undisturbed by later shearing. The pyroxenite locally grades into small discontinuous gabbroic zones (Hotz and others, 1972).

A small sliver of the westernmost part of the northern half of the roadless area is underlain by the Abrams Mica Schist, a part of the central metamorphic belt. The Abrams is a metasedimentary unit that consists of quartz-mica schist, calc-schist, micaceous marble, and intercalated amphibolite which underthrusts the ultramafic rocks of the Trinity ultramafic sheet (Irwin, 1977).

A large granodiorite pluton intrudes the ultramafic rocks south of Coffee Creek in the central part of the study area. The pluton has not been studied in detail, but is similar to the other large plutons in the surrounding area (Hotz and others, 1972). The southern part of the roadless area is adjacent to the Gibson Peak pluton on the southwest and the Granite Peak pluton on the south. Small discontinuous dikes of andesite, hornblende diorite, dacite, gabbro, diabase, and aplite intrude metamorphic and ultramafic rocks. The dikes range from 5 to $25 \mathrm{ft}$ in thickness, trend $\mathrm{N}$. $60^{\circ} \mathrm{W}$. to $\mathrm{N} .65^{\circ} \mathrm{E}$, and range in dip from $60^{\circ} \mathrm{N}$. to $60 \mathrm{~S}$. Many of these dikes are associated with mineralized zones outside of the roadless area (Hotz and others, 1972).

Unconsolidated Pleistocene and Holocene deposits occur in broad valleys and narrow stream drainages. Pleistocene glacial deposits along Coffee Creek, Swift Creek, and the Stuart Fork of the Trinity River include till, sand, gravel, and bouldery lateral and terminal moraines. Debris flows are common on steep 
slopes where serpentine and serpentinized ultramafic rocks are the principal bedrock materials. The flows consist of boulders and smaller stones firmly embedded in a green-gray matrix of silt and clay. Faint stratification and down-valley dipping imbrication of cobbles and boulders is common (Hotz and others, 1972).

Pleistocene stream-terrace deposits in the larger drainages in the area consist of unconsolidated gravels and sand in valley bottoms above the levels of present streams. The deposits range from 5 to $20 \mathrm{ft}$ thick and 25 to $50 \mathrm{ft}$ wide. Holocene deposits consist of stream-deposited detritus reworked from older stream terraces, glacial deposits, slope debris, and eroded and bedrock. Colluvium or slope wash mantles most of the slopes and consists of angular fragments of bedrock, up to $1 \mathrm{ft}$ across, loosely bonded by soll and vegetation. These deposits are as much as 15 to $25 \mathrm{ft}$ thick. In places the material creeps downslope into stream beds, and in other places, overlaps stream terrace deposits. Talus piles have accumulated below cliffs and steep bedrock slopes throughout the area (Hotz and others, 1972).

\section{GEOCHEMISTRY}

Approximately 67 percent (9650 acres) of the Lake Eleanor Roadless Area was included in the geochemical study by Hotz and others (1972). They collected 31 stream-sediment and 2 rock samples in or near the roadless area which were analyzed for 30 elements using a six-step semiquantitative emission spectrographic method. The sediments were also analyzed for copper and zinc using atomic absorption methods and for citrate soluble copper and heavy metals using colorimetric methods. The rock samples were analyzed for gold by atomic absorption methods and for mercury by instrumental methods.

In this study the remaining 33 percent of the roadless area was geochemically examined by the Geological Survey and the Bureau of Mines. The Geological Survey collected nine stream-sediment samples from Chinkhollow, Sugar Pine, Boulder, Little Boulder, Buckeye, Swift, and Davis Creeks, and from unnamed tributaries of Swift Creek the East Fork of the Stuart Fork of the Trinity River. The sediments were analyzed for 31 elements using a six-step semiquantative emission areas spectrographic method. Four sediment samples from streams that drain areas underlain predominantly by ultramafic rocks were also analyzed by fire assay for platinum group metals and gold.

U.S. Bureau of Mines personnel collected ten placer samples from stream gravels in the Sugar Pine, Boulder, Buckeye, Swift, and Davis Creeks. Pan concentrates were collected on a laboratory-sized Wilfley table, and the gold was handpicked or amalgamated and weighed. Analytical results are shown in table 1.

Hotz and others (1972) report that most stream-sediment and rock samples containing slightly anomalous amounts of several metals are more abundant in the western half of their study area than in the eastern half, which includes most of the Lake Eleanor Roadless Area. There are no localities in the eastern half of their study area where metals other than gold occur in anomalous concentrations. One pan concentrate collected on Battle Creek in the roadless area yielded 3.2 parts per million (ppm) in gold. Sediment samples collected upstream and downstream of the pan sample location, however, failed to reveal any detectable gold. Supplemental sampling in the remainder of the Lake Eleanor 
Roadless Area revealed no significantly anomalous concentrations of metallic elements. The four stream-sediment samples collected by the Geological Survey contain no more than $0.007 \mathrm{ppm}$ gold. The Bureau of Mines recovered gold values of no more than $\$ 0.04$ per cubic yard from their samples based on gold valued at $\$ 500$ per troy ounce.

Analytical data (table 1) indicate that conclusions reached by Hotz and others (1972) in their study can be extended to include all of the Lake Eleanor Roadless Area. Threshold values (table 1) of gold, silver, copper, lead, zinc, mercury, and molybdenum are taken from Hotz and others (1972) and are based on cumulative frequency curves of analytical data. Values above this threshold are considered to be anomalous. Threshold values for the few rock samples may be highly biased because of the selective sampling techniques used.

The combined sampling program of the Geological Survey and the Bureau of Mines revealed no evidence that the Lake Eleanor Roadless Area contains significant concentrations of metals. Background levels for chromium, nickel, and cobalt are fairly high throughout the roadless area because chromite is a common accessory mineral in ultramafic rocks and nickel and cobalt are common minor elements. Stream-sediment values are far above background levels for rocks and sediments, but are not significant because chromite, nickel, and cobalt are highly resistant to, and are concentrated by, weathering and erosion processes. No significant cobalt-nickel-bearing laterites or concentrations of chromite are in the area and no platinum was detected in any stream-sediments at the lower limit of determination of $10 \mathrm{ppm}$ (Hotz and others, 1972). Platinum and palladium values in table 1 are, at most, only half of the normal background value for ultramafic rocks in North America (Wright and Fleischer, 1965).

\section{MINING ACTIVITY}

Mining activity in the region surrounding the Lake Eleanor Roadless Area dates from 1848 following the discovery of gold at Reading Bar, about 20 to 30 $m i$ to the southwest on the Trinity River. This discovery prompted prospecting in the streams of the Trinity River drainage close to the study area. Placer deposits were initially mined by small-scale techniques and hydraulic methods through the late $1800^{\prime}$ 's and until recently, by dredging (0'Brien, 1965). An estimated $\$ 35$ million in placer gold has been recovered from the entire Trinity River system since mining began in northern California (Clark, 1970).

Two principal areas of gold production in the upper Trinity River area were the Trinity Center district and the Carrville district. The Trinity Center district was placer mined beginning in 1851, whereas the Carrville district, which includes Union Creek and Coffee Creek, west and northwest of the study area, was extensively mined from the early 1870's through the 1890's and, intermittently, through the late 1940's (Miller, 1890; Averil1, 1941; 0'Brien, 1965). Coffee Creek was noted for yielding coarse gold, but work along it was usually hampered by the size and number of boulders, and by lack of stream grade and volume of gravel. Numerous placer claims along Coffee Creek several miles outside the roadless area produced small quantities of gold (Logan, 1926; Averill, 1941).

Parts of Buckeye Creek east of the Lake Eleanor Roadless Area (sec. 19, T. 37 N., R. 2 W., Mount Diablo Meridian, and secs. 23, 24, T. 37 N., R. 8 W., Mount Diablo Meridian) were placer mined from the late 1940's to early 1950's. 
The gravels were 8-10 ft thick on decomposed granodiorite bedrock and were worked intermittently by ground sluicing. Operators reported a recovery of 30 oz of gold and $2 \mathrm{oz}$ of silver from $2600 \mathrm{yd}^{3}$ of gravel. Subsequent operations with a dragline dredge proved too difficult because of numerous boulders and hard bedrock (O'Brien, 1965). Recently, on clalms near the roadless area along the Trinity River and Coffee Creek, mining by portable suction dredges has producéd gold from sma11, submerged, high-grade pockets of auriferous gravel.

Lode mining was not significant in Trinity County until the discovery in 1875 of the Deadwood mining district, $20 \mathrm{mi}$ south of the roadless area. Many deposits were discovered on auriferous quartz veins cutting slates and diorite porphyry (O'Brien, 1965). Shortly thereafter gold was produced from lode mines in the Carrville district. The principal producers in this district were the Trinity Bonanza King mine $(\$ 1,250,000)$ and the Headlight mine $(\$ 500,000)$, both 5-7 mi east of the roadless area.

Within $7 \mathrm{mi}$ of the roadless area, many mines were located between 1890 and 1900 on quartz-bearing fissure veins cutting a variety of rock types (MacDonald, 1913; O'Brien, 1965). These mines included the Modoc (Wagner) and Burner mines, both 2-3 mi northeast of the roadless area, the (New) Blue Jay mine, $1.5 \mathrm{mi}$ to the east, the Dorleska and Yellow Rose mines, both 1-2 mi west of the area, and the Golden Jubilee and Liberty (Poeth) mines. At these latter two mines, both less than one mile northeast of the roadless area, northeast-trending quartz veins up to $16 \mathrm{ft}$ thick that cut granodiorite yielded free gold and gold tellurides. The veins are associated with mafic dikes and commonly are sheared or fractured by post-mineralization faulting.

The Golden Jubilee is developed by seven adits; the Liberty by a 145-ft shaft and $60 \mathrm{ft}$ of drifts. Production from the Golden Jubllee was 4,319 oz of gold, 1,995 oz of copper, and $160 \mathrm{lb}$ of lead. No production from either property has been recorded since 1941. All of these mines contributed to gold production valued at over $\$ 2$ million by 1910 (MacDonald, 1913; Averi11, 1941; Clark, 1970). Smaller mines and old claims within $5 \mathrm{mi}$ of the northern boundary of the roadless area include the Blue Jacket, True Blue, Mohawk, Gold Dollar, Iron Dike, Copper Queen, Strode (Oro Grande), Non-Pareil, Chapman, Boddecker, Gypsy Queen group, Jumbo claims, Hardscrabble, and the Marcelleus group. At these mining claims, either assessment work only was done, or production was very small (MacDonald, 1913; 0'Brien, 1965). None of these mines are currently active.

No patented or unpatented mining claims or mining leases are within the Lake Eleanor Roadless Area. Ground and air reconnaissance failed to reveal any evidence of past lode or placer mining activity. There are no records of mining activity in the roadless area.

\section{MINERAL RESOURCES POTENTIAL}

On the basis of an investigation by Hotz and others (1972), and herein, there is in the Lake Eleanor Roadless Area no evidence of a potential for metallic mineral resources. Gravels along the Trinity River and Coffee Creek have yielded gold in the past, but streams that drain the roadless area contain no significant gold values, indicating that these streams did not drain the principle source areas of the placer gold mined in the vicinity of the roadless area. The streams examined in the Lake Eleanor Roadless Area are shallow, narrow, and choked with boulders, consequently, they do not contain benches or 
large volumes of stream gravel where significant amounts of gold might be expected.

The roadless area is underlain by granodiorite and ultramafic rocks which, in nearby mines, contain fissure veins carrying gold and silver minerals. At the Golden Jubilee and Liberty mines, less than one mile northeast of the roadless area, the veins are fractured and do not crop out prominently. Similar veins, if present in the roadless area, would probably be covered by glacial debris or soll on all but the steepest slopes. Extensive exploration and mining activity throughout the surrounding area almost eliminates the possibility of finding additional surface lode gold deposits in the Lake Eleanor Roadless Area. Subsurface quartz veins with gold may be present in the area, because such quartz veins commonly occur in sheared ultramafic rocks close to granitic plutons, especially in zones associated with mafic dikes (MacDonald, 1913). Geochemical analyses of rock and stream-sediment samples, however, indicate no evidence of a potential for undiscovered or concealed mineral deposits within the roadless area. Sand and gravel are common in most drainages, but tonnages are small. There is no evidence of a potential for energy resources in the Lake Eleanor Roadless Area.

\section{REFERENCES CITED}

Averi11, C. V., 1941, Mineral resources of Trinity County: California Journal of Mines and Geology, v. 37, p. 1-89.

Clark, W. B., 1970, Gold districts of California: California Division of Mines and Geology Bulletin 193, $186 \mathrm{p}$.

Davis, G. A., Holaway, M. J., Lipman, P. W., and Romey, W. D., 1965, Structure, metamorphism, and plutonism in the south-central Klamath Mountains,

California: Geological Soc. Amer. Bulletin v. 76, no. 8, p. 1547-1552.

Hotz, P. E., Thurber, H. K., Marks, L. Y., and Evans, R. K., 1972, Mineral resources of the Salmon-Trinity Alps Primitive Area, California with a section on an aeromagnetic survey and interpretation by Andrew Griscom: U.S. Geological Survey Bulletin 1371-B, 267 p.

Irwin, W. P., 1977, Review of Paleozoic rocks of the Klamath Mountains, in Stewart, J. H., Stevens, C. H., and Fritche, A. E., eds., Paleozoic paleogeography of the Western United States: Society of Economic Paleontologists and Mineralogists, Pacific Section, Pacific Coast Paleogeographic Symposium, Apri1 22, 1977, p. 441-454.

Logan, C. A., 1926, Trinity County, Annual Report of the State Mineralogist v. 22: California Mining Bureau, p. 1-67.

MacDonald, D. F., 1913, Gold and silver--Notes on the gold lodes of the Carrville district, Trinity County, California: U.S. Geological Survey Bulletin 530 , P. 99-41.

Miller, W. P., 1890, Trinity County, Annual Report of the State Mineralogist v. 10: California Mining Bureau, p. 695-727. 
0'Brien, J. C., 1965, Mines and mineral resources of Trinity County, California: California Division of Mines and Geology County Report 4, 125 p.

Strand, R. G., compller, 1962, Geologic map of California, Redding Sheet--0laf P. Jenkins edition: California Division of Mines and Geology, Geologic Atlas of California, scale $1: 250,000$.

Wright, T. L., and Fleischer, M., 1965, Geochemistry of platinum metals: U.S. Geological Survey Bulletin 1214-A, 24 p. 


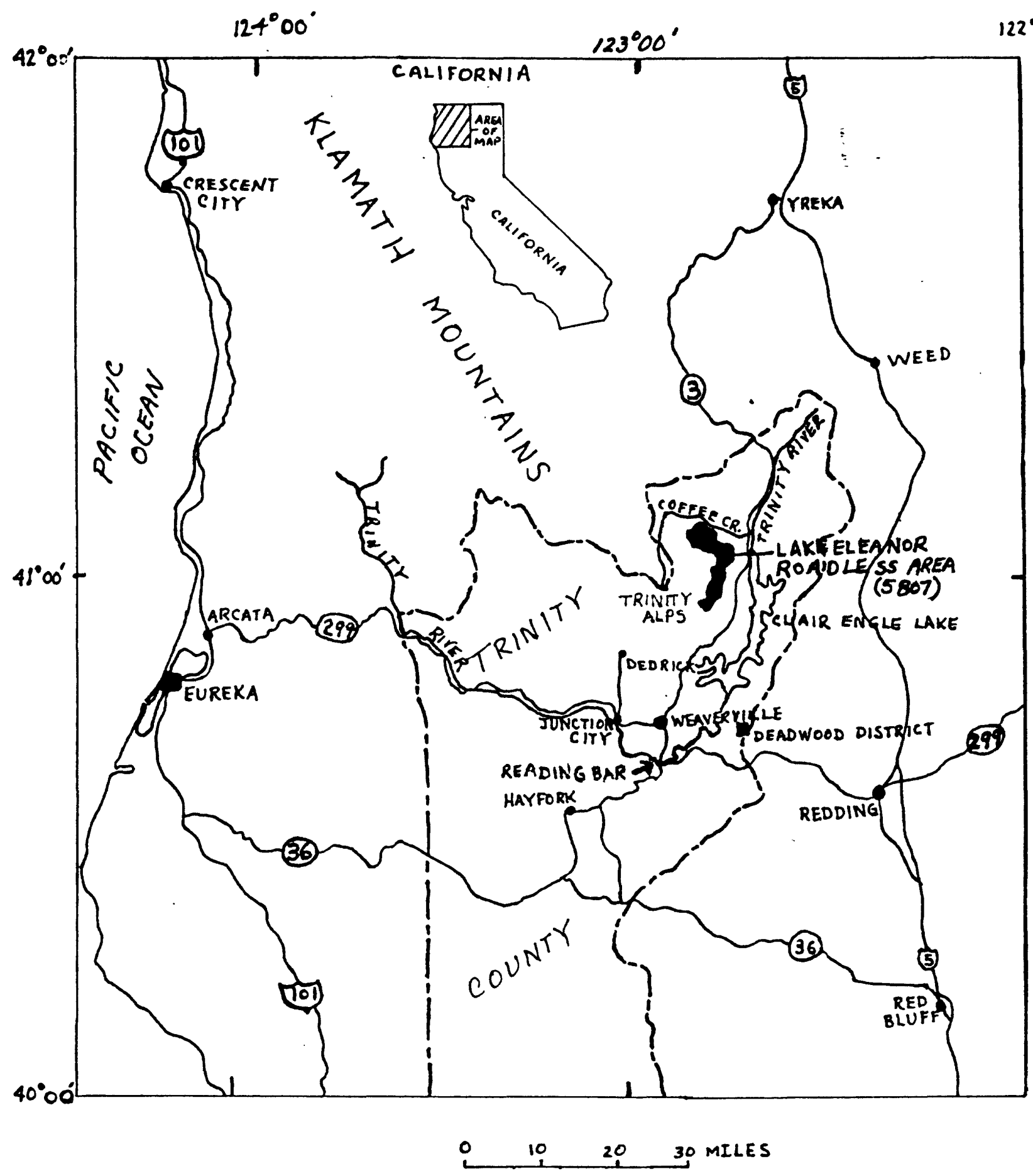

Figure 1.--Location of the Lake Eleanor Roadless $A$ ea in the Klamath Mountains, Trinity County, California. 


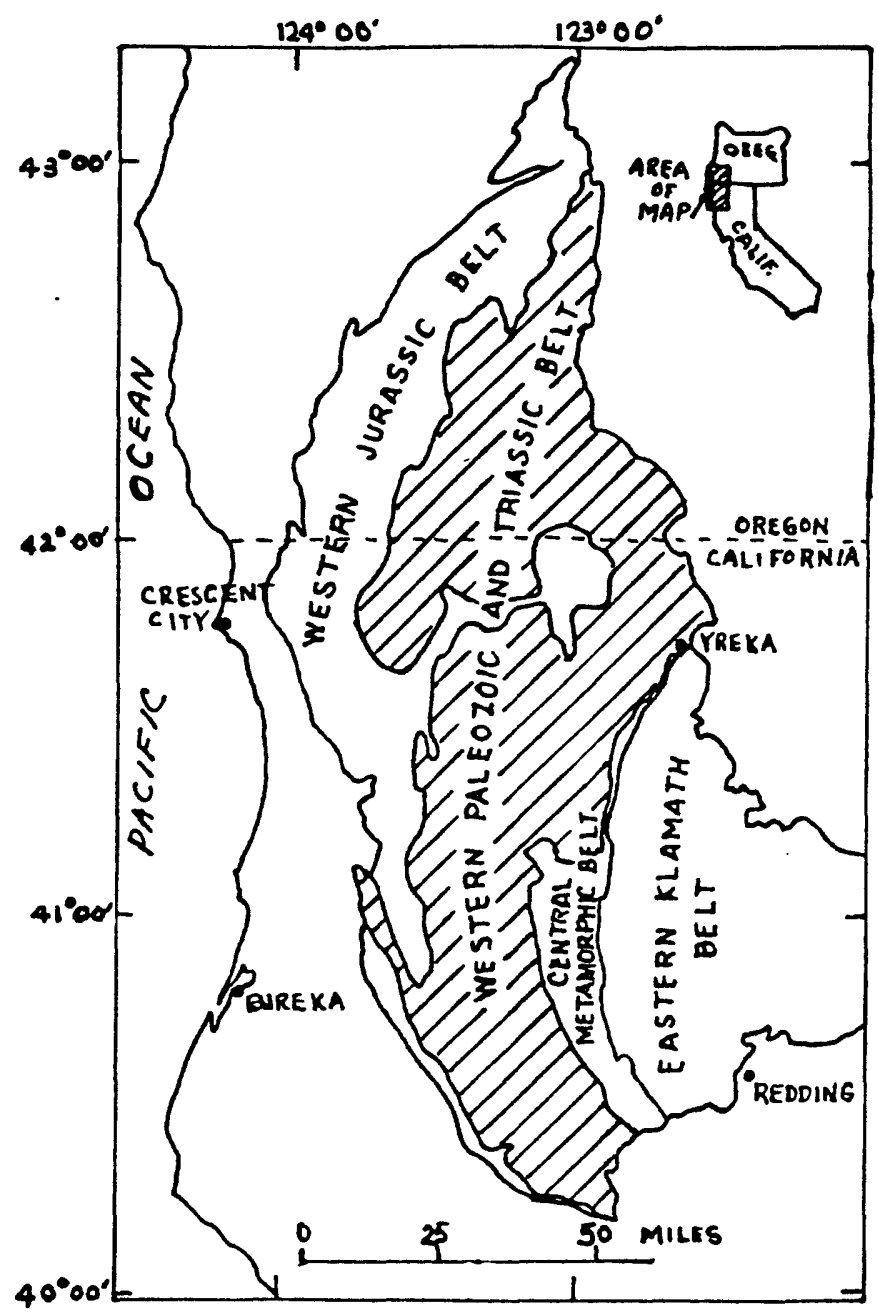

Figure 2.--Generalized map showing the lithic belts of the Klamath Mountains geologic province,

California and Oregon (after Irwin, 1977). 


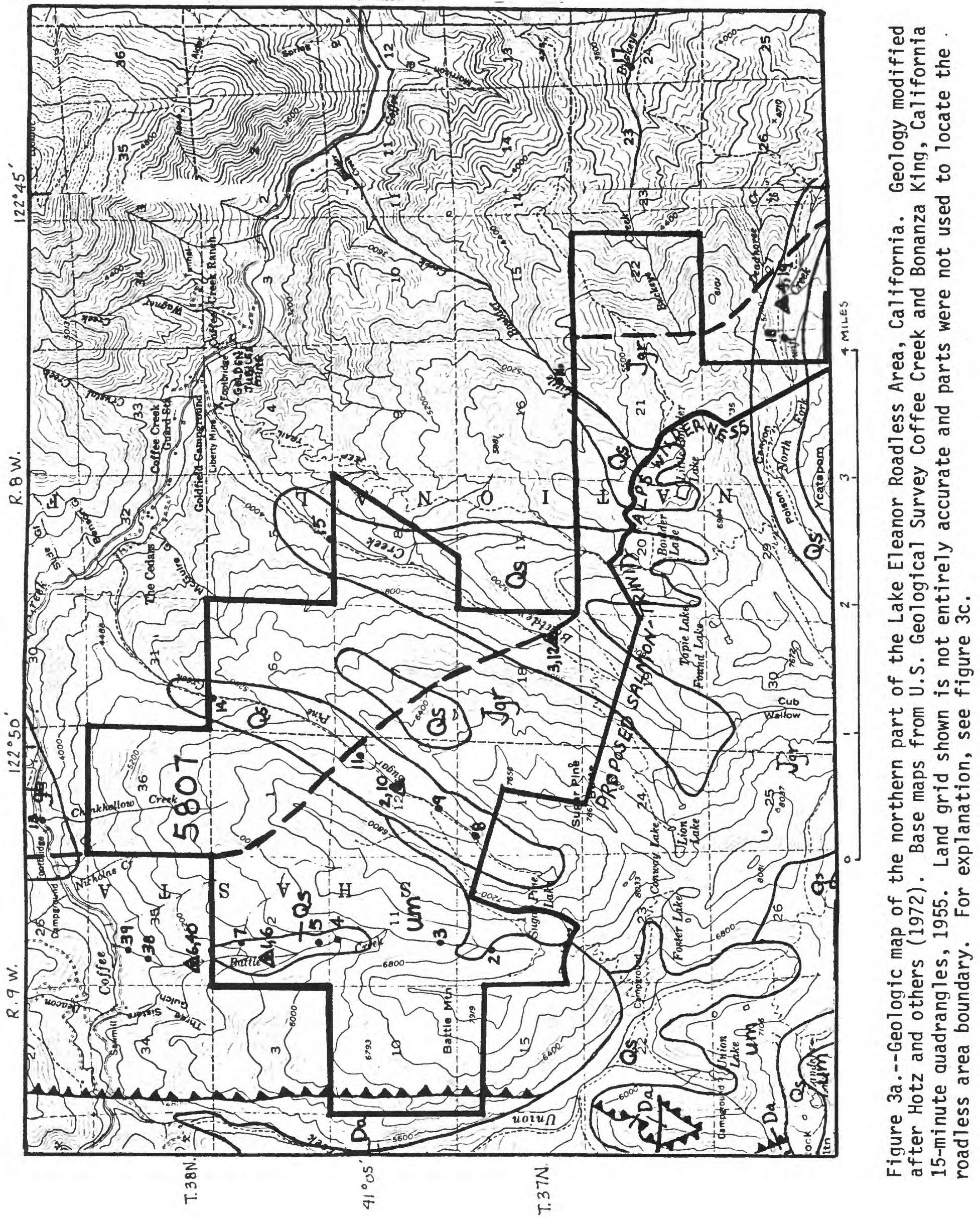




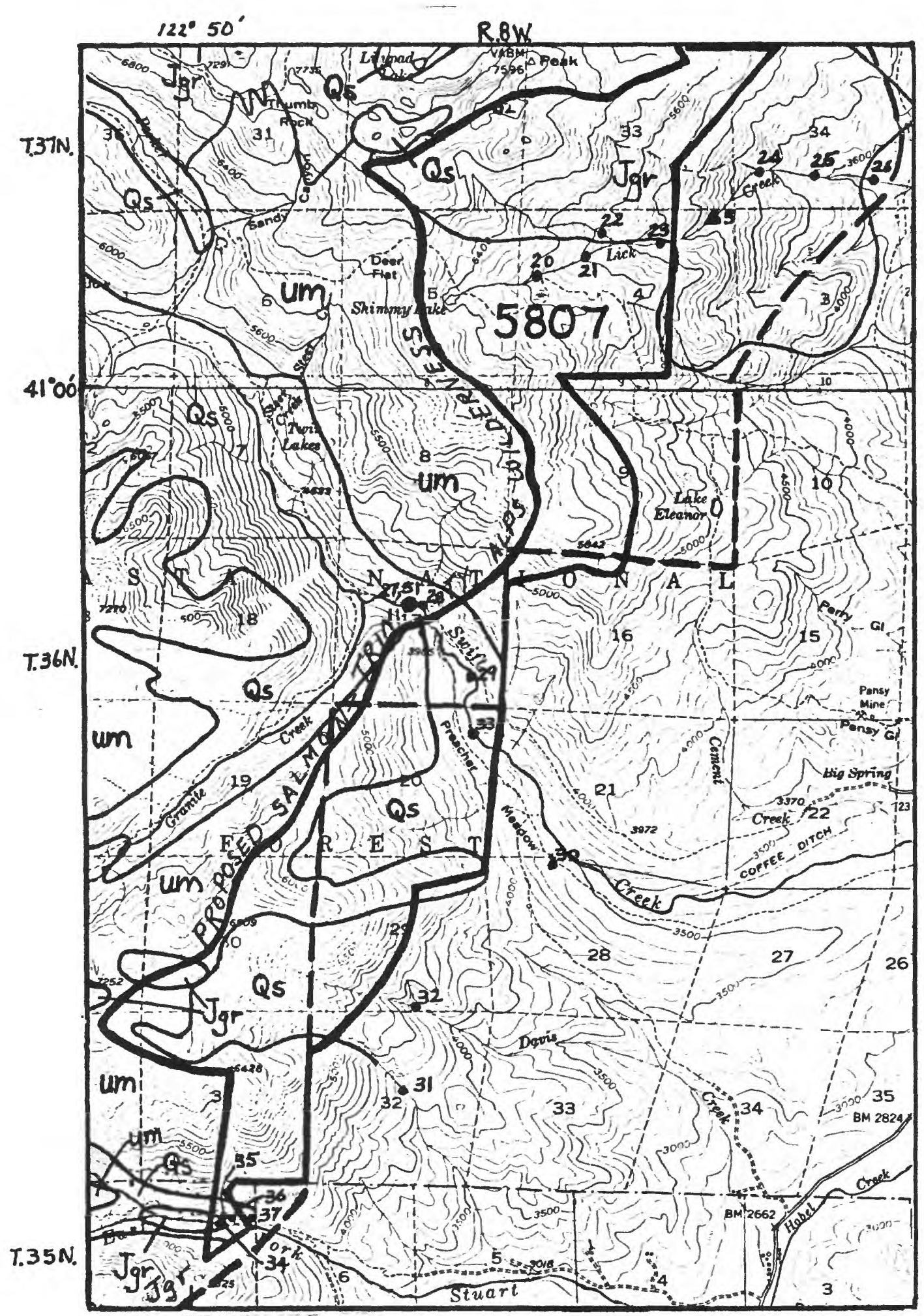

EI

\section{CONTOUR, INTERVAL 100 FEET}

Figure 3b.--Geologic map of the southern part of the Lake Eleanor Roadless Area, California. Geology modified after Hotz and others (1972). Base maps from U.S. Geological Survey Coffee Creek and Trinity Dam, California 15-minute ouadrangles, 1955 and 1950 respectively. Land grid shown is not entirely accurate and parts were not used to locate the roadless area boundary. For explanation, see figure $3 c$. 


\section{EXPLANATION}

QS SURFICIAL DEPOSITS (QUATERNARY)

Jgr GRANITIC ROCKS (JURASSIC)

$\mathrm{gb}$ GABBROIC ROCKS (JURASSIC OR OLDER)

Um ULTRAMAFIC ROCKS (JURASSIC OR OLDER)

Da ABRAMS MICA SCHIST (DEVONIAN)

APPROXIMATE BOUNDARY OF ROADLESS AREA

- CONTACT--Approximately located

THRUST FAULT--Approximately located; sawteeth on upper plate

- - BOUNDARY OF SALMON-TRINITY ALPS PRIMITIVE AREA STUDY (HOTZ AND OTHERS, 1972)

$0^{2} \quad$ ROCK SAMPLE--Locality and number (see table 1)

- 33 STREAM-SEDIMENT SAMPLE--Locality and number (see table 1)

$\Delta^{5} \quad$ PAN-CONCENTRATE SAMPLE--Locality and number (see table 1)

$0^{27,51}$ STREAM-SEDIMENT AND ROCK SAMPLES AT SAME LOCATION--Locality and number (see table 1); the first number refers to the stream-sediment sample

$\Delta^{2,10}$ STREAM-SEDIMENT AND PAN-CONCENTRATE SAMPLES AT SAME LOCATION--Locality and numbers (see table 1); the first number refers to the pan-concentrate sample

Figure 3c.--Explanation for the geologic map (fig $3 a, b$ ) of the Lake Eleanor Roadless Area, California. 


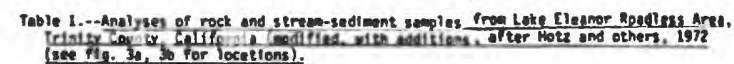

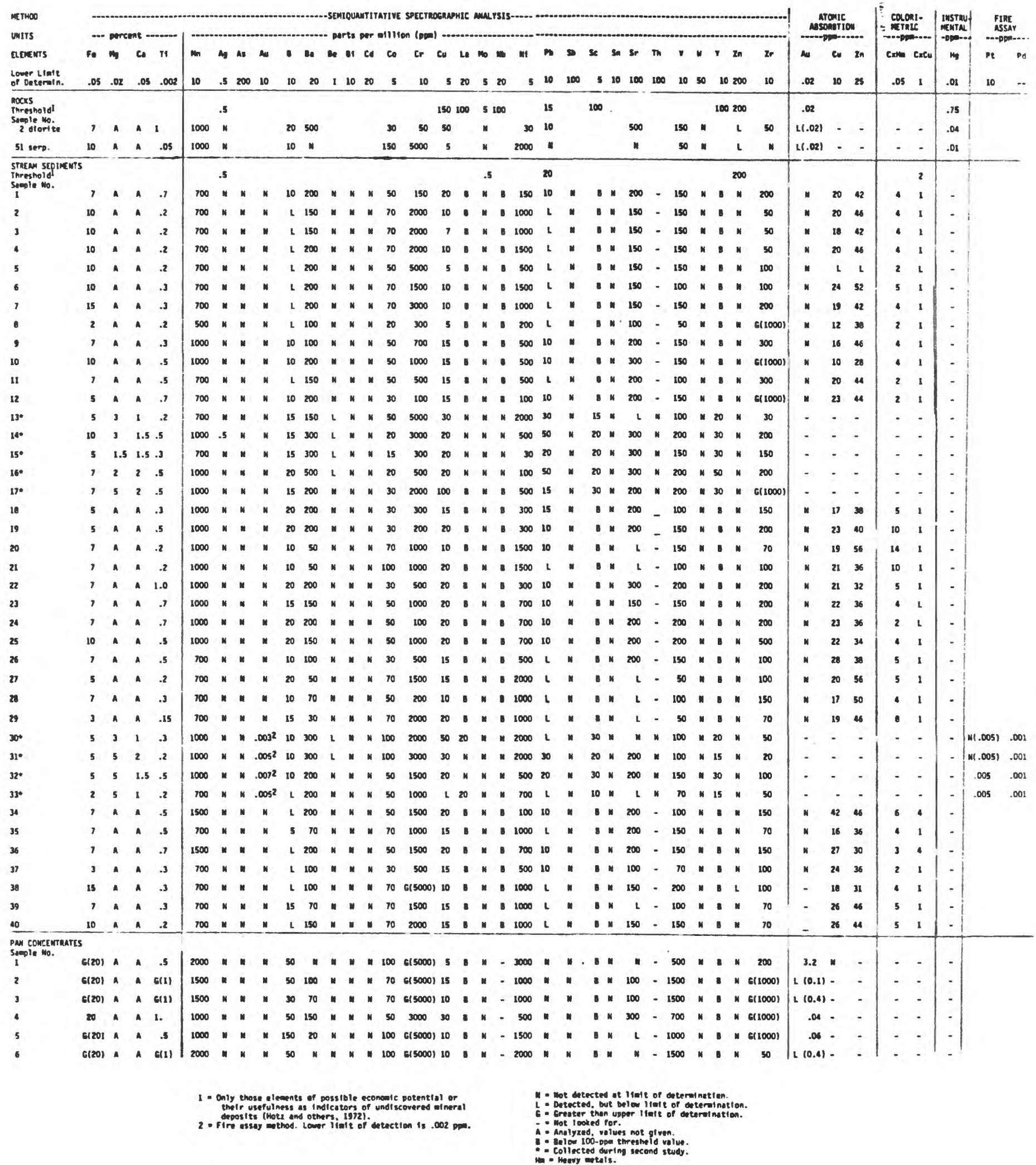

